\title{
Neuroprotective delivery platforms as an adjunct to mechanical thrombectomy
}

\author{
Robin M. Babadjouni, MS, ${ }^{1}$ Brian P. Walcott, MD, ${ }^{2}$ Qinghai Liu, MD, ${ }^{1}$ Matthew S. Tenser, MD, ${ }^{2}$ \\ Arun P. Amar, MD, ${ }^{2}$ and William J. Mack, MD ${ }^{1,2}$
}

\author{
'Zilkha Neurogenetic Institute and 2Department of Neurosurgery, Keck School of Medicine, University of Southern California, Los \\ Angeles, California
}

\begin{abstract}
Despite the success of numerous neuroprotective strategies in animal and preclinical stroke models, none have effectively translated to clinical medicine. A multitude of influences are likely responsible. Two such factors are inefficient recanalization strategies for large vessel occlusions and suboptimal delivery methods/platforms for neuroprotective agents. The recent endovascular stroke trials have established a new paradigm for large vessel stroke treatment. The associated advent of advanced mechanical revascularization devices and new stroke technologies help address each of these existing gaps. A strategy combining effective endovascular revascularization with administration of neuroprotective therapies is now practical and could have additive, if not synergistic, effects. This review outlines past and current neuroprotective strategies assessed in acute stroke trials. The discussion focuses on delivery platforms and their potential applicability to endovascular stoke treatment.
\end{abstract}

https://thejns.org/doi/abs/10.3171/2017.1.FOCUS16514

KEY WORDS acute ischemic stroke; mechanical thrombectomy; neuroprotection

$\mathrm{T}$ o date, few effective therapies exist for treatment

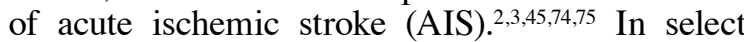
individuals, intravenous tissue plasminogen activator (tPA) improves outcomes when administered within 4.5 hours of symptom onset. ${ }^{37}$ Limitations of intravenous thrombolysis have led to the development of alternative revascularization and reperfusion strategies. ${ }^{11,77,78}$ The 2015 endovascular stroke trials demonstrate that the prompt use of new-generation mechanical thrombectomy devices, particularly stent retrievers, significantly improves functional independence in the setting of large-vessel stroke compared with best medical management alone..$^{14,17,33,48 \text {, }}$ 81,92 These trials marshaled a new treatment paradigm that has revolutionized acute stroke care. A greater number of stroke patients are now eligible for established therapies with potential for substantially improved functional outcomes. However, significant limitations exist with regard to prehospital management, timely selection for intravenous tPA or endovascular therapy, and multidisciplinary coordination of posttreatment stroke and ICU care. ${ }^{4,6}$ Perhaps most importantly, both intravenous thrombolysis and mechanical revascularization target vessel recanalization rather than tissue reperfusion and are highly dependent on time.

Despite recent advances, the rates of functional independence $(14 \%-58 \%)$ following mechanical thrombectomy are poor compared with the efficient rates of recanalization $(60 \%-90 \%))^{7,34}$ The mechanism underlying this paradox remains elusive. One hypothesis, first proposed in the cardiology literature, is the "no-reflow phenomenon." Supporters advance the concept of minimal capillary reperfusion despite adequate recanalization. ${ }^{28}$ Restoration of blood flow is thought to alter the microvascular milieu, creating a proinflammatory state that renders affected microvascular beds incompetent. ${ }^{21,72,98}$ While blood flows through the large vessels, there is resistance at the capillary level. A lack of functional reperfusion causes marginally viable penumbral tissue to be recruited into the ische-

\footnotetext{
ABBREVIATIONS AIS = acute ischemic stroke; $\mathrm{APC}=$ activated protein $\mathrm{C} ; \mathrm{BM}-\mathrm{MNC}=$ bone marrow mononuclear cell; $\mathrm{DWI}=$ diffusion-weighted imaging; $\mathrm{MCA}=$ middle cerebral artery; $\mathrm{mRS}=$ modified Rankin Scale; NIHSS = National Institutes of Health Stroke Scale; $r$ PerC = remote ischemic perconditioning (preconditioning); tPA = tissue plasminogen activator.
}

ACCOMPANYING EDITORIAL DOI: 10.3171/2017.1.FOCUS1728.

SUBMITTED December 1, 2016. ACCEPTED January 5, 2017.

INCLUDE WHEN CITING DOI: 10.3171/2017.1.FOCUS16514. 
mic core. The discrepancy between recanalization rates and functional outcome underscores the need for further advancements in stroke therapy.

Endovascular treatment is recommended in appropri ately selected patients who have symptom onset within 6 hours of presentation. ${ }^{46}$ However, The International Management of Stroke (IMS III) trial found that for every 30-minute delay in the time to reperfusion, there was a $12 \%-15 \%$ relative reduction in the likelihood of good clinical outcome..$^{52}$ Not only is the time window for revascularization short, there is a bias toward better outcome earlier in the treatment period. As thrombectomy devices and recanalization rates have improved significantly, alternative points along the stroke treatment pathway must now be engaged to improve outcomes. Extension of the treatment window by preserving "at-risk" brain tissue is a logical target.

Adjunct neuroprotective administration in the setting of mechanical revascularization could address these 2 therapeutic gaps. Neuroprotective agents may promote reperfusion at the capillary level in the region of the target tissue and could potentially increase the time window for effective recanalization (by preserving brain tissue and decreasing hemorrhage rates). New-generation mechanical thrombectomy delivery systems provide a unique opportunity to effectively administer neuroprotectants in the treatment of AIS. This review focuses on neuroprotective strategies and their potential ability to "freeze time" by limiting ischemic damage while a patient proceeds through the acute stroke pathway. ${ }^{27,50,56,96}$ The Discussion introduces novel platforms for delivery of neuroprotective therapies and specifically highlights the potential utility of neuroprotection as an adjunct before, during, and after mechanical thrombectomy.

\section{Barriers to Implementation of Neuroprotective Strategies}

Thousands of preclinical animal studies have demonstrated benefits of neuroprotective therapies in the setting of experimental acute stroke. ${ }^{93}$ However, none of these treatment strategies have been widely translated to human patients. ${ }^{32}$ Species-specific differences in brain structure and function, lack of sex heterogeneity, and a shortage of trials in the setting of relevant comorbidities are potential reasons for translational failures ${ }^{47}$ The Stroke Treatment Academic Industry Roundtable (STAIR) recommendations were created in an effort to develop a rigorous standard in the transition of preclinical neuroprotectant studies to clinical trials. 25

Factors that limit the potential for treatment agents to reach target territories (ischemic penumbra) can prevent significant changes in clinical stroke outcomes even if neuroprotective therapies could otherwise salvage ischemic tissue. Such factors include lack of perfusion due to thrombus burden, inefficient delivery methods, and poor collateral vessels. ${ }^{31}$ In the past, neuroprotectant delivery platforms were tailored and optimized to supplement definitive revascularization strategies, such as endovascular therapy. Mechanical revascularization presents a nowproven procedure with no potential drug-drug interactions that can be administered in series or parallel with neuroprotective agents. This combined, and potentially synergistic, therapeutic strategy holds great promise.

The sections below outline the various time points, with respect to mechanical thrombectomy treatment, at which putative neuroprotective agents may be administered.

\section{Prehospital Delivery Methods}

In AIS, the volume of the ischemic core expands into previously salvageable penumbral tissue as time progresses. ${ }^{10,42,49,71}$ A slower rate of early diffusion-weighted imaging (DWI) growth is associated with greater penumbral salvage following tissue reperfusion. ${ }^{95}$ Neuroprotective strategies could slow the rate of ischemic growth prior to endovascular AIS treatment (Table 1). Successful application would broaden eligibility for endovascular therapy and ultimately improve functional outcomes for each patient by shifting the time-to-reperfusion/functional outcome curve. The Field Administration of Stroke TherapyMagnesium (FAST-MAG) trial was the first to deliver a neuroprotective agent during the hyperacute period, the "golden hour" after stroke onset. ${ }^{82}$ Although FAST-MAG did not achieve its primary efficacy end point (that prehospital administration of magnesium sulfate during the hyperacute phase of AIS would reduce disability at 90 days), it established safety and feasibility of a novel prehospital delivery platform. ${ }^{83,84}$ The investigators demonstrated that a study agent could be effectively delivered to patients during the first 60 minutes after stroke onset by ambulance paramedics and established methods and protocols that can be used in future trials. An under-recognized, yet important aspect of the trial was the implementation of a 2 -stage screening process that paramedics used to identify potential study patients. The first stage consisted of assessment via the Los Angeles Prehospital Stroke Screen (LAPSS) ${ }^{53}$ This is a diagnostic inventory that takes minutes to perform, exhibits high sensitivity and specificity, and is widely used among ambulance personnel worldwide. The second stage incorporated physician assessment over the telephone. These streamlined steps allow neuroprotective agents to be safely administered while patients were delivered to the hospital (parallel processing). In a subset analysis, investigators studied patients who received prehospital treatment with magnesium or placebo initiated less than 2 hours from symptom onset and underwent endovascular treatment. Magnesium therapy still showed no effect; however, the investigators calculated that the strategy exposed patients to 3 hours and 28 minutes of potential neuroprotective exposure prior to endovascular treatment.

An in-depth discussion of novel neuroprotective agents amenable to this type of delivery mechanism is beyond the scope of this paper. However, there are a number of promising therapies, such as NA-1, glyburide, activated protein $\mathrm{C}$, and uric acid, that have recently passed Phase 2 clinical trials. ${ }^{19,40,64,85}$

It is hypothesized that the failure of many neuroprotective strategies is due to the fact that agents only target 1 point in a mechanistic pathway. Hypothermia, however, is a promising therapy that exhibits a wide range of cel- 
TABLE 1. Prehospital delivery methods

\begin{tabular}{|c|c|c|c|c|c|c|}
\hline $\begin{array}{l}\text { Reference/ } \\
\text { Registration } \\
\text { No. }\end{array}$ & Study Name & $\begin{array}{l}\text { Study } \\
\text { Type }\end{array}$ & $\begin{array}{c}\text { Neuroprotectant/ } \\
\text { Neuroprotective } \\
\text { Mode }\end{array}$ & Treatment Method & Primary Outcome & Results \\
\hline $\begin{array}{l}\text { Saver et al., } \\
\quad 2015\end{array}$ & FAST-MAG & RCT & $\begin{array}{l}\text { Magnesium } \\
\text { sulfate }\end{array}$ & $\begin{array}{l}\text { IV w/in } 45 \text { mins of } \\
\text { stroke symptoms }\end{array}$ & $\mathrm{mRS}$ score at 90 days & $\begin{array}{l}\text { Prehospital infusion of } \\
\text { magnesium sulfate } \\
\text { was safe w/in } 2 \text { hours } \\
\text { of stroke symptoms } \\
\text { but did not improve } \\
\text { disability outcome at } \\
90 \text { days }\end{array}$ \\
\hline $\begin{array}{l}\text { Krieger et al., } \\
2001\end{array}$ & COOL AID & $\begin{array}{l}\text { Open pilot } \\
\text { study }\end{array}$ & $\begin{array}{l}\text { Hypothermia } \\
\left(32^{\circ} \mathrm{C}\right)\end{array}$ & $\begin{array}{c}\text { Systemic hypothermia } \\
\text { w/in } 6.2 \pm 1.3 \mathrm{hrs}\end{array}$ & $\begin{array}{l}\text { Safety \& feasibility of } \\
\text { moderate hypothermia }\end{array}$ & $\begin{array}{l}\text { Induced hypothermia } \\
\text { found to be safe w/ } \\
\text { mRS score of } 3.1 \pm 2.3 \\
\text { at } 3 \text { mos }\end{array}$ \\
\hline NCT01584167 & iCOOL2 & $\mathrm{RCT}$ & Hypothermia & EMCOOLS Flex.Pads & $\begin{array}{l}\text { Change in brain tempera- } \\
\text { ture during } 1 \mathrm{hr} \text { after } \\
\text { start of cooling }\end{array}$ & Ongoing \\
\hline $\begin{array}{l}\text { Meng et al., } \\
2012\end{array}$ & $\begin{array}{l}\text { Upper-limb ischemic } \\
\text { preconditioning } \\
\text { prevents recurrent } \\
\text { stroke in intracrani- } \\
\text { al arterial stenosis }\end{array}$ & $\begin{array}{l}\text { Prospec- } \\
\quad \text { tive } \\
\text { random- } \\
\text { ized } \\
\text { study }\end{array}$ & $\begin{array}{l}\text { Repetitive } \\
\text { bilateral-arm } \\
\text { ischemic pre- } \\
\text { conditioning }\end{array}$ & $\begin{array}{l}5 \text { brief cycles of } \\
\text { bilateral upper-limb } \\
\text { ischemia, twice } \\
\text { daily for } 300 \text { con- } \\
\text { secutive days }\end{array}$ & $\begin{array}{l}\text { Time point of the 1st } \\
\text { stroke recurrence } \\
\text { event }\end{array}$ & $\begin{array}{l}\text { Incidence of recurrent } \\
\text { stroke was reduced to } \\
5 \% \& 7.9 \% \text { at } 90 \& 300 \\
\text { days, respectively }\end{array}$ \\
\hline $\begin{array}{c}\text { Hougaard et } \\
\text { al., } 2014\end{array}$ & $\begin{array}{l}\text { Remote Ischemic } \\
\text { Perconditioning as } \\
\text { an Adjunct Therapy } \\
\text { to Thrombolysis in } \\
\text { Patients With Acute } \\
\text { Ischemic Stroke }\end{array}$ & $\begin{array}{l}\text { Open-label } \\
\text { blinded } \\
\text { outcome } \\
\text { proof-of- } \\
\text { concept } \\
\text { study }\end{array}$ & rPerC & $\begin{array}{l}\text { Prehospital rPerC as } \\
\text { an adjunct to treat- } \\
\text { ment } w / \text { intrave- } \\
\text { nous alteplase. }\end{array}$ & $\begin{array}{l}\text { Penumbral salvage as } \\
\text { defined by the vol of } \\
\text { the perfusion-diffusion } \\
\text { mismatch not pro- } \\
\text { gressing to infarction } \\
\text { after } 1 \text { mo }\end{array}$ & $\begin{array}{l}\text { rPerC reduced tissue risk } \\
\text { of infarction using vox- } \\
\text { el-wise analysis after } \\
\text { adjustment for baseline } \\
\text { perfusion \& diffusion } \\
\text { lesion severity }\end{array}$ \\
\hline
\end{tabular}

IV = intravenous; $\mathrm{RCT}$ = randomized clinical trial.

lular mechanisms ${ }^{97}$ Systemic cooling to a temperatures of $32^{\circ} \mathrm{C}$ and $34^{\circ} \mathrm{C}$ for 24 hours has been shown to increase survival and improve neurological outcome in patients with spontaneous circulation restoration after cardiac arrest due to ventricular fibrillation. ${ }^{1}$ Induced hypothermia was first found feasible and safe in acute ischemic stroke in the Cooling for Acute Ischemic Brain Damage (COOL AID) open pilot study.$^{54}$ EuroHYP-1 is an ongoing Phase 3 clinical trial that employs systemic cooling to decrease body temperature to a target between $34^{\circ} \mathrm{C}$ and $35^{\circ} \mathrm{C}$. Hypothermia is initiated within 6 hours of stroke onset and maintained for 24 hours. The primary outcome is the modified Rankin Scale (mRS) score at 90 days. Patients in this study are either cooled with an intravenous infusion of $20 \mathrm{ml} / \mathrm{kg}$ refrigerated normal saline $\left(4^{\circ} \mathrm{C}\right)$ over 30-60 minutes or a surface cooling method, depending on local practice. ${ }^{91}$ Although patients in this study begin the cold infusions when they enter the hospital, intrave- nous cooling can easily be administered in the prehospital setting. The appeal of a cold infusion is that it is easy to deliver, widely accessible (i.e., refrigerator in ambulance), and portable. Further methods of cooling and their effects on brain temperature are also being studied. The iCOOL2 clinical trial is testing a novel, noninvasive, surface cooling system called the EMCOOLS Flex.Pads (Emergency Medical Cooling Systems AG) (clinical trial registration no. NCT01584167 [clinicaltrials.gov]).

Remote ischemic perconditioning (preconditioning) (rPerC) has been shown to be neuroprotective in animal models of cerebral ischemia. ${ }^{38} \mathrm{rPerC}$ occurs when ischemia induced in one organ leads to ischemic tolerance in others, with the protective effect attributed to the activation of multiple endogenous defense mechanisms. ${ }^{76}$ The safety of rPerC was tested in a randomized single-center study in patients with myocardial infarction. The treatment was found to be safe and effective in myocardial salvage. ${ }^{15}$ 
TABLE 2. Neuroprotectant administration coupled with mechanical thrombectomy

\begin{tabular}{|c|c|c|c|c|c|c|}
\hline $\begin{array}{l}\text { Reference/ } \\
\text { Registration } \\
\text { No. }\end{array}$ & Study Name & $\begin{array}{l}\text { Study } \\
\text { Type }\end{array}$ & $\begin{array}{l}\text { Neuroprotectant/ } \\
\text { Neuroprotective } \\
\text { Mode }\end{array}$ & Treatment Method & Primary Outcome & Results \\
\hline Hill et al., 2012 & $\begin{array}{l}\text { The Safety and Efficacy } \\
\text { of NA-1 in Patients with } \\
\text { latrogenic Stroke after } \\
\text { Endovascular Aneu- } \\
\text { rysm Repair (ENACT) }\end{array}$ & $\mathrm{RCT}$ & NA-1 & $\begin{array}{l}\text { IV infusion of NA-1 after } \\
\text { endovascular aneurysm } \\
\text { repair }\end{array}$ & $\begin{array}{l}\text { Safety as well as no. \& } \\
\text { vol of new ischemic } \\
\text { strokes defined by } \\
\text { MRI at } 12-95 \text { hrs } \\
\text { after infusion }\end{array}$ & $\begin{array}{l}\text { NA-1 group sustained } \\
\text { fewer ischemic in- } \\
\text { farcts than placebo } \\
\text { group as measured } \\
\text { by DWI \& FLAIR }\end{array}$ \\
\hline
\end{tabular}

Bilateral-arm rPerC was first found to be neuroprotective in reducing the incidence of stroke and transient ischemic attack in patients with symptomatic intracranial arterial stenosis. ${ }^{61}$ rPerC was then tested as an adjunct to thrombolysis in patients with acute ischemic stroke in an openlabel, prehospital, paramedic-administered study.44 This study used MRI lesion volumes (as opposed to functional outcomes) to determine effect size. Upper-arm rPerC was performed for a total of 4 cycles by ambulance staff and was discontinued on arrival to the stroke unit. The study showed no overall benefit. However, when the findings were adjusted for baseline severity of hypoperfusion, a voxel-by-voxel analysis showed increased tissue survival after 1 month in the treatment group. This suggests that prehospital rPerC may have neuroprotective capacity. Currently, the Remote Ischemic Conditioning in Acute Brain Infarction (RESCUE BRAIN) trial is underway. This study examines whether rPerC during ischemic stroke $(<6$ hours) reduces brain infarct size at 24 hours. ${ }^{73}$ The primary end point is the absolute difference in brain infarct volume measured by DWI MRI from baseline to 24 hours, in the intervention versus control groups. The authors state that if RESCUE BRAIN shows effect on infarct volume, they would conduct a larger trial using a clinical primary end point. In the setting of acute stroke, $\mathrm{rPerC}$ is a promising prehospital neuroprotective adjunct to mechanical thrombectomy. The treatment is easy to administer and has already demonstrated positive results in patients with myocardial infarction and those with symptomatic intracranial stenosis.

\section{Neuroprotectant Administration Coupled With Mechanical Thrombectomy}

Activated protein C (APC) is a promising neuroprotectant agent. APC is an endogenous serine protease that is generated in multiple cell types within the neurovascular unit during the response to cerebral ischemia. ${ }^{35,99}$ Like hy- pothermia, APC targets several pathological mechanisms of the ischemic cascade. The Safety Evaluation of 3K3AAPC in Ischemic Stroke (RHAPSODY) Phase 2 clinical trial is assessing the safety, pharmacokinetics, and preliminary efficacy of multiple increasing intravenous doses of 3K3A-APC (recombinant variant of human APC) in combination with tPA, mechanical thrombectomy or both (registration no. NCT02222714). Although the neuroprotectant delivery route is intravenous, this is the first trial of its kind to incorporate mechanical thrombectomy with the use of a putative neuroprotectant. Just as the FAST-MAG trial set the stage for prehospital delivery of neuroprotectants, the RHAPSODY trial has established the use of mechanical thrombectomy with the concurrent administration of neuroprotective agents. ${ }^{58}$ The study authors needed to develop criteria that ensured patients are treated with current evidence-based standards for mechanical thrombectomy while, at the same time, allowing for assessment of efficacy for a neuroprotective agent. The door-to-needle times, imaging criteria, and National Institutes of Health Stroke Scale (NIHSS) scores established for inclusion in this study will set the standard for future investigations for combined neuroprotective agents and mechanical thrombectomy procedures (Table 2).

The Safety and Efficacy of NA-1 in Patients With Iatrogenic Stroke After Endovascular Aneurysm Repair (ENACT) study established safety and feasibility of neuroprotective strategies in the setting of endovascular procedures. ${ }^{40}$ ENACT was a double-blind, randomized, controlled trial that found that NA-1 could be safely administered to patients undergoing endovascular repair of ruptured and unruptured intracranial aneurysms. Investigators assessed whether NA-1 reduced the volume and number of iatrogenic ischemic strokes (detection via MRI). NA-1 was administered at the conclusion of the procedures and was found to reduce the number of iatrogenic embolic strokes but not the overall volumes of 
TABLE 3. Intraarterial neuroprotectant delivery

\begin{tabular}{|c|c|c|c|c|c|c|}
\hline $\begin{array}{l}\text { Referencel } \\
\text { Registration } \\
\text { No. }\end{array}$ & Study Name & $\begin{array}{l}\text { Study } \\
\text { Type }\end{array}$ & $\begin{array}{l}\text { Neuroprotectant/ } \\
\text { Neuroprotective } \\
\text { Mode }\end{array}$ & Treatment Method & Primary Outcome & Results \\
\hline NCT02235558 & $\begin{array}{l}\text { Superselective Administra- } \\
\text { tion of Verapamil During } \\
\text { Recanalization in Acute } \\
\text { Ischemic Stroke (SAVER-I) }\end{array}$ & RCT & Magnesium & $\begin{array}{l}\text { Intraarterial verapamil adminis- } \\
\text { tered immediately following } \\
\text { intraarterial thrombolysis } \\
\text { (either tPA or mechanical } \\
\text { thrombectomy) }\end{array}$ & $\begin{array}{l}\text { Presence or absence of } \\
\text { intracranial hemorrhage }\end{array}$ & Ongoing \\
\hline NCT02912663 & $\begin{array}{l}\text { Magnesium and Verapamil } \\
\text { After Recanalization in } \\
\text { Ischemia of the Cerebrum: } \\
\text { a Clinical and Translational } \\
\text { Study (MAVARIC) }\end{array}$ & RCT & $\begin{array}{l}\text { Magnesium \& } \\
\text { verapamil }\end{array}$ & $\begin{array}{l}\text { Selective intraarterial adminis- } \\
\text { tration of verapamil \& mag- } \\
\text { nesium immediately after } \\
\text { mechanical thrombectomy }\end{array}$ & $\begin{array}{l}\text { Presence or absence of } \\
\text { intracranial hemorrhage }\end{array}$ & Ongoing \\
\hline
\end{tabular}

lesions. This study establishes feasibility of intravenous delivery of a putative neuroprotective agent during neuroendovascular procedures. The investigators have leveraged their delivery platform to test the same agent in AIS. The Safety and Efficacy of NA-1 in Subjects Undergoing Endovascular Thrombectomy for Stroke (ESCAPE-NA1) Phase 3 clinical trial expands the use of NA-1 to patients with major AIS (registration no. NCT02930018). AIS patients with a small, established infarct core and favorable collateral circulation are treated with a single $2.6-\mathrm{mg}$ intravenous dose of NA-1 or placebo once selected for mechanical thrombectomy. The primary study outcome is global disability, with secondary measures of functional dependence, neurological outcome, activities of daily living, and mortality rate.

\section{Intraarterial Neuroprotectant Delivery}

Inadequate delivery of neuroprotective therapies to target tissue has been a concern in the setting of emergent large vessel occlusion. A large thrombus prevents the direct passage of blood, oxygen, nutrients, and any systemically administered agents. It is posited that potential neuroprotectants reach the penumbral tissue through collateral circulation. ${ }^{31,87}$ New-generation endovascular techniques allow for selective intraarterial drug delivery, a concept first described as endovascular restorative neurosurgery. ${ }^{7}$ Neuroprotective agents can be administered regionally through guide catheters positioned in the carotid or vertebral artery. Alternatively, treatments can be administered directly through microcatheters positioned at the face of, or beyond, the occlusive lesion. The benefits of intraarterial delivery of neuroprotectants are numerous. A high concentration/dose ratio can be achieved in a small, targeted volume of the brain, ultimately leading to lower systemic toxicity. Delivery can be executed rapidly and accessed repeatedly, while limiting perturbations of neural tissue inherent to traditional surgical routes of access..$^{5,57}$

The neuroendovascular community has a significant experience with intraarterial delivery platforms outside of stroke treatment. Lessons from these endeavors can be translated directly to mechanical thrombectomy pro- cedures. Isolated or daily intraarterial infusion of spasmolytic agents (papaverine, verapamil, nitroglycerine) is common practice in the setting of cerebral vasospasm. ${ }^{8,24}$ Continuous intraarterial infusion of nimodipine has recently been reported. Safety of active infusion over the duration of 2 weeks was documented. ${ }^{12,41,65}$ The safety of continuous intraarterial infusion of nimodipine has implications for the delivery of neuroprotectants. Current trials (see below) use short-term, intraoperative, administration of neuroprotective agents. However, with the advent of continuous intraarterial treatment, the delivery of neuroprotectants can, theoretically, be administered safely for longer durations after stroke.

Intraarterial delivery of chemotherapeutics for brain tumors was first described in the 1950s. ${ }^{29}$ With the advancement of endovascular techniques, the concept of superselective intraarterial cerebral infusion was established. This allows for the selective targeting of afferent tumor vessels, enabling the infusion of a chemotherapeutic agent to a localized area. Selective microcatheter delivery of a targeted agent to brain tumors was first described in $2009 .{ }^{79}$ To date, superselective intraarterial cerebral infusion has been successfully leveraged for the treatment of high-grade gliomas and retinoblastomas. , $^{3,67,86}$

In large-vessel stroke, intraarterial delivery of neuroprotectants can occur prior to, or following, clot extraction. If an agent is delivered distal to a thrombus prior to recanalization, it will likely remain in the tissue bed until flow is restored. This has implications on both efficacy and toxicity. However, if the neuroprotectant therapy is delivered after recanalization, the agent will be subject to the same first-pass effects that might be seen in other tissue beds. Stent retriever catheters allow for distal delivery once a thrombus is traversed, while aspiration with distal catheters would only allow local/regional administration, as they do not typically cross the face of the clot. Several ongoing trials are examining intraarterial delivery platforms in the setting of acute stroke (Table 3). The Intra-arterial Magnesium Administration for Acute Stroke trial examines the effect of intraarterial high concentration magnesium administration in patients with AIS (registration no. 
TABLE 4. Alternate endovascular delivery methods

\begin{tabular}{|c|c|c|c|c|c|c|}
\hline Reference & Study Name & $\begin{array}{l}\text { Study } \\
\text { Type }\end{array}$ & $\begin{array}{c}\text { Neuroprotectant/ } \\
\text { Neuroprotective } \\
\text { Mode }\end{array}$ & Treatment Method & Primary Outcome & Results \\
\hline
\end{tabular}

NCT01502761). This safety and feasibility study is the first to directly quantify levels of neuroprotectants in the region of ischemia. Similarly, Superselective Administration of Verapamil During Recanalization in Acute Ischemic Stroke (SAVER-I) examines the safety of verapamil as a neuroprotective agent administered intraarterially immediately following intraarterial thrombolysis (either tPA or mechanical thrombectomy) (registration no. NCT02235558). This study uses newer generation mechanical thrombectomy devices, and it uses a guide in the region previously burdened by a clot, administering $10 \mathrm{mg}$ verapamil $/ 20 \mathrm{ml}$ normal saline over 20 minutes. By assessing 2 neuroprotective agents with relatively benign safety profiles, these 2 studies have established a paradigm for administering other intraarterially delivered neuroprotectants.

The Magnesium and Verapamil After Recanalization in Ischemia of the Cerebrum: a Clinical and Translational Study (MAVARIC) is a Phase 2 clinical trial investigating the safety and feasibility of superselective intraarterial administration of verapamil and magnesium immediately after mechanical thrombectomy (registration no. NCT02912663); $10 \mathrm{mg}$ verapamil/10 ml normal saline and $1000 \mathrm{mg}$ magnesium sulfate $/ 20 \mathrm{ml}$ normal saline are administered over 20 minutes using a microcatheter into vessels that were previously obstructed by thrombus. Outcome measures include symptomatic intracranial hemorrhage and systemic side effects.

Stem cells have been delivered via intraarterial platforms in many clinical stroke trials. ${ }^{80}$ Although stem cells are neuroregenerative, rather than neuroprotective, their intraarterial delivery is worth considering in this discussion. At this time, the optimal mode of stem cell delivery (intracerebral, intraventricular, subarachnoid, intraarterial, intraperitoneal, intravenous, and intranasal) remains unclear. However, the intraarterial route has shown promise. ${ }^{62}$ Battistella et al. first assessed the use of autologous bone marrow mononuclear cells (BM-MNCs) in 6 patients with nonacute middle cerebral artery (MCA) stroke within 90 days of symptom onset..$^{13}$ A large inner diameter microcatheter (SL 1018 Boston Scientific, Target Therapeutics) was used to infuse the stem cells for approximately 10 minutes into the $\mathrm{M}_{1}$ portion of the MCA. As the trial did not include a control group, efficacy could not be ascer- tained. However, the study did demonstrate feasibility and safety. Another Phase 1-2 clinical trial aimed to assess the safety, feasibility, and effect of BM-MNC transplantation in subacute MCA stroke. ${ }^{63} \mathrm{BM}-\mathrm{MNC}$ were injected into the $\mathrm{M}_{1}$ segment of the affected MCA region at low pressure 5-9 days after stroke. Once again, the authors found that intraarterial transplantation of BM-MNCs in subacute MCA stroke is feasible and safe. Using similar delivery methods, another BM-MNC trial demonstrated a $40 \%$ rate of good clinical outcome (mRS score $\leq 2$ ) and $30 \%$ satisfactory clinical improvement (mRS score of 0 in patients with NIHSS score $<8$, mRS score of $0-1$ in patients with NIHSS scores of 8-14, or mRS scores of $0-2$ in patients with NIHSS score $>14$ ) in their study population. ${ }^{30}$

\section{Alternative Endovascular Delivery Methods}

We previously described the potential benefits of intravenous cooling during AIS. This strategy has been extended to a direct endovascular approach (Table 4). The Cooling for Acute Ischemic Brain Damage (COOL AID) feasibility trial was the first trial to use triple-looped, helically wound, heat-exchange balloon catheters that were placed in the inferior vena cava via femoral vein access. The investigators found that moderate hypothermia is feasible in the setting of AIS with the aid of an endovascular cooling device. ${ }^{20}$ The Intravascular Cooling in the Treatment of Stroke (ICTuS) trial expanded on this principle. The study demonstrated that endovascular cooling with a proactive antishivering regimen can be accomplished in awake stroke patients. ${ }^{58}$ This study employed the use of a heparin-coated flexible metal catheter with a metallic heat transfer surface that facilitates extraction of heat from the blood as it flows by the catheter. Later, the ICTuS-Longer window (ICTuS-L) trial was developed to determine if endovascular catheterization and cooling could be performed safely in patients treated with thrombolytic therapy. The investigators found no bleeding complications in patients who underwent catheterization. However, the ICTuS-L trial demonstrated an increase in risk of pneumonia in patients receiving endovascular cooling. ${ }^{36,39}$ The Phase 2 ICTuS trial confirmed the safety and feasibility of intravascular therapeutic hypothermia in patients undergoing 
TABLE 5. Neuroprotective delivery following mechanical thrombectomy

\begin{tabular}{|c|c|c|c|c|c|c|}
\hline Study & Study Name & $\begin{array}{l}\text { Study } \\
\text { Type }\end{array}$ & $\begin{array}{l}\text { Neuroprotectant/ } \\
\text { Neuroprotective } \\
\text { Mode }\end{array}$ & Treatment Method & Primary Outcome & Results \\
\hline NCT01976936 & $\begin{array}{l}\text { Neuroprotection With Statin Ther- } \\
\text { apy for Acute Recovery Trial } \\
\text { Phase } 2 \text { (NeuSTART2) }\end{array}$ & RCT & Statin & $\begin{array}{l}\text { Randomization of standard dose lo- } \\
\text { vastatin vs short-term high-dose } \\
\text { lovastatin } 640 \mathrm{mg} / \text { day for } 3 \text { days } \\
\text { within } 24 \text { hrs of symptom onset }\end{array}$ & $\begin{array}{l}\text { Primary safety } \\
\text { outcome: major } \\
\text { hepatic toxicity or } \\
\text { rhabdomyolysis }\end{array}$ & Ongoing \\
\hline NCT01369069 & $\begin{array}{l}\text { Stroke Hyperglycemia Insulin Net- } \\
\text { work Effort (SHINE) Trial }\end{array}$ & RCT & Insulin & $\begin{array}{l}\text { Treatment of hyperglycemic acute } \\
\text { ischemic stroke patients with } \\
\text { targeted glucose concentration } \\
(80-130 \mathrm{mg} / \mathrm{dl})\end{array}$ & $\begin{array}{l}\text { mRS at } 3 \text { mos \& } \\
\text { severe hypogly- } \\
\text { cemia (primary } \\
\text { safety outcome) }\end{array}$ & Ongoing \\
\hline NCT02054429 & $\begin{array}{l}\text { Intensive Insulin Therapy With Tight } \\
\text { Glycemic Control to Improve } \\
\text { Outcomes After Endovascular } \\
\text { Therapy for Acute Ischemic } \\
\text { Stroke }\end{array}$ & RCT & Insulin & $\begin{array}{l}\text { Insulin infusion (minimal rate of } 2 \\
\text { U/hr while maintaining blood } \\
\text { glucose btwn } 90 \& 120 \mathrm{mg} / \mathrm{dl} \text { ) } \\
\text { immediately after endovascular } \\
\text { therapy \& continued for } 48 \mathrm{hrs}\end{array}$ & $\mathrm{mRS}$ at 30 days & Ongoing \\
\hline
\end{tabular}

thrombolytic therapy. The protocol changes implemented to reduce pneumonia risk appeared to have failed; however, the sample size was small. ${ }^{59}$

\section{Neuroprotective Delivery Following Mechanical Thrombectomy}

Despite efforts to achieve vessel recanalization and reperfusion, there remains a percentage of patients who are recalcitrant to endovascular therapy and go on to suffer ischemic injury. In principle, inhibition of inflammatory pathways, prevention of excitotoxicity, reduction of apoptosis, and mitigation of the development of vasogenic edema should improve cellular survival in the area of ischemia and surrounding tissue, commonly referred to as secondary brain injury. Unfortunately, many of the pharmacological treatments developed to target these mechanisms have failed to demonstrate reproducible clinical benefit when evaluated in human subjects. Notably, recent trials of erythropoietin ${ }^{70}$ and progesterone,${ }^{90}$ when used to mitigate secondary brain injury resulting from traumatic mechanisms, did not demonstrate any superiority over placebo medication.

One of the more promising agents aimed at preventing secondary brain injury recently evaluated in a Phase 2 randomized clinical trial is a sulfonylurea receptor 1 antagonist (intravenous delivery) (registration no. NCT01794182). ${ }^{51,88}$ Inhibition of this receptor has the potential to reduce the development of vasogenic edema fol- lowing ischemic stroke, a key mediator of secondary brain injury. ${ }^{94}$ Its mechanism rests on an understanding of the ionic movement through the SUR1-TRPM4 nonselective cation channel, which is upregulated in the setting of ischemia. In animal studies, it has been demonstrated that this channel can be effectively blocked with glyburide, a medication approved by the FDA for diabetes treatment. Results of this trial demonstrated that the medication Cirara (Remedy Pharmaceuticals) resulted in a 53\% mortality reduction when compared with placebo and the amount of brain swelling (measured by midline shift) was also reduced by half when compared with placebo. This evidence, along with an excellent safety profile, suggests that Cirara has the potential to dramatically change the treatment of ischemic stroke, and supports further investigation in a Phase 3 trial (Table 5).

The Efficacy and Safety of Neu2000KWL in Treating Acute Ischemic Stroke Receiving Endovascular Therapy (ENIS I) trial is a study examining the safety and efficacy of Neu2000KWL, a multitarget drug designed to prevent both excitotoxicity mediated by the $N$-methyl-D-aspartic (NMDA) receptor and free-radical toxicity (registration no. NCT02831088). It combines intravenous drug administration just prior to endovascular therapy with 9 consecutive infusions of Neu2000KWL at 12-hour intervals following mechanical thrombectomy.

Although not classically considered neuroprotectants, multiple treatment strategies/agents (glycemic control, 
statins) have been used to decrease infarct volume, mitigate cerebral edema, and improve clinical outcome in the setting of acute stroke. ${ }^{89}$ Trials are being designed to specifically assess the efficacy of these therapies in the subset of large vessel occlusions. Most recently, studies have leveraged some of these treatment strategies as adjuncts after mechanical thrombectomy. The use of statin therapy has been established in primary and secondary stroke prevention. ${ }^{9,66}$ Furthermore, statin administration has been shown to improve recovery after AIS. A population-based prospective cohort study found that initiation of new statin therapy ( $<72$ hours after stroke) was associated with improved 7-day survival, along with good functional outcomes at 7 days and 1 year. ${ }^{69}$ Statin use initiated within 3 days of stroke hospitalization is strongly associated with improved poststroke survival. By contrast, withdrawal of statin therapy in the hospital was associated with worsened survival. ${ }^{26} \mathrm{~A}$ more recent meta-analysis of observational studies and randomized trials found that statin therapy at stroke onset was associated with improved outcome. ${ }^{68}$ The sum of these findings has led investigators to develop clinical trials. The Neuroprotection with Statin Therapy for Acute Recovery Trial (NeuSTART) found that doses of lovastatin up to $8 \mathrm{mg} / \mathrm{kg}$ daily for 3 days after AIS was tolerable. ${ }^{22}$ NeuSTART2 is currently studying the safety and efficacy of low dose (80 mg daily) and high dose (640 mg daily) statins administered within 24 hours of symptom onset for 3 days (registration no. NCT01976936). The Administration of Statin On Acute Ischemic Stroke Patient Trial (ASSORT) is a Phase 4 clinical trial examining the effect of statin (atorvastatin $20 \mathrm{mg}$ or pitavastatin $4 \mathrm{mg}$ or rosuvastatin $5 \mathrm{mg}$ ) initiated for a week after AIS (registration no. NCT02549846).

Hyperglycemia is a common finding in patients with AIS and is associated with larger infarct volumes, poor clinical outcomes, and increased risk of mortality. ${ }^{18,23,55}$ The Stroke Hyperglycemia Insulin Network Effort (SHINE) trial is a Phase 3 study examining 1400 hyperglycemic patients who receive either sliding-scale subcutaneous insulin or continuous intravenous insulin for up to 72 hours, beginning within 12 hours of stroke onset (registration no. NCT01369069). The study is powered to detect a $7 \%$ absolute difference in favorable outcome at 3 months. This trial is currently ongoing and will help elucidate the proper management parameters for hyperglycemic AIS patients. ${ }^{16}$ Another study is examining the effects of Exenatide, a GLP-1 analog. A decreased risk of hypoglycemia may afford an advantage over insulin therapy in the acute management of hyperglycemia in the setting of AIS. ${ }^{60}$ Tight glycemic control in AIS is now being leveraged as an adjunct to mechanical thrombectomy in The Intensive Insulin Therapy With Tight Glycemic Control to Improve Outcomes After Endovascular Therapy for Acute Ischemic Stroke clinical trial (registration no. NCT02054429). This study will examine the effects of intensive insulin therapy versus standard glycemic control in nondiabetic patients presenting within 8 hours of ischemic stroke who have undergone mechanical thrombectomy. The primary outcome is the mRS score at 90 days, and secondary outcome is DWI infarct volume.

\section{Conclusions}

Acute stroke treatment has undergone a seismic shift over the past 2 years. A period of rapid device development was coupled with expansion in stroke systems of care. Patients with emergent large vessel occlusion are being diverted to endovascular centers more efficiently and undergoing successful mechanical thrombectomy procedures. Functional outcomes are improving. Combination therapies could be the next great advancement: administering neuroprotective agents and mechanical revascularization procedures in series or parallel could potentially increase efficacy and lengthen the treatment window for acute stroke.

\section{Acknowledgments}

This research was supported by National Institutes of Health grant ES024936 to W.J.M.

\section{References}

1. Abramson DH, Dunkel IJ, Brodie SE, Marr B, Gobin YP: Superselective ophthalmic artery chemotherapy as primary treatment for retinoblastoma (chemosurgery). Ophthalmology 117:1623-1629, 2010

2. Adams HP Jr, del Zoppo G, Alberts MJ, Bhatt DL, Brass L, Furlan A, et al: Guidelines for the early management of adults with ischemic stroke: a guideline from the American Heart Association/American Stroke Association Stroke Council, Clinical Cardiology Council, Cardiovascular Radiology and Intervention Council, and the Atherosclerotic Peripheral Vascular Disease and Quality of Care Outcomes in Research Interdisciplinary Working Groups: The American Academy of Neurology affirms the value of this guideline as an educational tool for neurologists. Circulation 115:e478e534, 2007

3. Ahmed N, Kellert L, Lees KR, Mikulik R, Tatlisumak T, Toni D: Results of intravenous thrombolysis within 4.5 to 6 hours and updated results within 3 to 4.5 hours of onset of acute ischemic stroke recorded in the Safe Implementation of Treatment in Stroke International Stroke Thrombolysis Register (SITS-ISTR): an observational study. JAMA Neurol 70:837-844, 2013

4. Akbik F, Hirsch JA, Cougo-Pinto PT, Chandra RV, Simonsen CZ, Leslie-Mazwi T: The evolution of mechanical thrombectomy for acute stroke. Curr Treat Options Cardiovasc Med 18:32, 2016

5. Amar AP, Zlokovic BV, Apuzzo ML: Endovascular restorative neurosurgery: a novel concept for molecular and cellular therapy of the nervous system. Neurosurgery 52:402413, 2003

6. Audebert HJ, Saver JL, Starkman S, Lees KR, Endres M: Prehospital stroke care: new prospects for treatment and clinical research. Neurology 81:501-508, 2013

7. Badhiwala JH, Nassiri F, Alhazzani W, Selim MH, Farrokhyar F, Spears J, et al: Endovascular Thrombectomy for Acute Ischemic Stroke: A Meta-analysis. JAMA 314:18321843,2015

8. Badjatia N, Topcuoglu MA, Pryor JC, Rabinov JD, Ogilvy CS, Carter BS, et al: Preliminary experience with intra-arterial nicardipine as a treatment for cerebral vasospasm. AJNR Am J Neuroradiol 25:819-826, 2004

9. Baigent C, Blackwell L, Emberson J, Holland LE, Reith C, Bhala N, et al: Efficacy and safety of more intensive lowering of LDL cholesterol: a meta-analysis of data from 170,000 participants in 26 randomised trials. Lancet 376:1670-1681, 2010 
10. Bandera E, Botteri M, Minelli C, Sutton A, Abrams KR, Latronico N: Cerebral blood flow threshold of ischemic penumbra and infarct core in acute ischemic stroke: a systematic review. Stroke 37:1334-1339, 2006

11. Barreto AD, Albright KC, Hallevi H, Grotta JC, Noser EA, Khaja AM, et al: Thrombus burden is associated with clinical outcome after intra-arterial therapy for acute ischemic stroke. Stroke 39:3231-3235, 2008

12. Bashir A, Andresen M, Bartek J Jr, Cortsen M, Eskesen V, Wagner A: Intra-arterial nimodipine for cerebral vasospasm after subarachnoid haemorrhage: Influence on clinical course and predictors of clinical outcome. Neuroradiol J 29:72-81, 2016

13. Battistella V, de Freitas GR, da Fonseca LM, Mercante D, Gutfilen B, Goldenberg RC, et al: Safety of autologous bone marrow mononuclear cell transplantation in patients with nonacute ischemic stroke. Regen Med 6:45-52, 2011

14. Berkhemer OA, Fransen PS, Beumer D, van den Berg LA, Lingsma HF, Yoo AJ, et al: A randomized trial of intraarterial treatment for acute ischemic stroke. N Engl J Med 372:11-20, 2015

15. Bøtker HE, Kharbanda R, Schmidt MR, Bøttcher M, Kaltoft $\mathrm{AK}$, Terkelsen CJ, et al: Remote ischaemic conditioning before hospital admission, as a complement to angioplasty, and effect on myocardial salvage in patients with acute myocardial infarction: a randomised trial. Lancet 375:727-734, 2010

16. Bruno A, Durkalski VL, Hall CE, Juneja R, Barsan WG, Janis $S$, et al: The Stroke Hyperglycemia Insulin Network Effort (SHINE) trial protocol: a randomized, blinded, efficacy trial of standard vs. intensive hyperglycemia management in acute stroke. Int J Stroke 9:246-251, 2014

17. Campbell BC, Mitchell PJ, Kleinig TJ, Dewey HM, Churilov L, Yassi N, et al: Endovascular therapy for ischemic stroke with perfusion-imaging selection. N Engl J Med 372:1009_ 1018,2015

18. Capes SE, Hunt D, Malmberg K, Pathak P, Gerstein HC: Stress hyperglycemia and prognosis of stroke in nondiabetic and diabetic patients: a systematic overview. Stroke 32:2426-2432, 2001

19. Chamorro A, Amaro S, Castellanos M, Segura T, Arenillas J, Martí-Fábregas J, et al: Safety and efficacy of uric acid in patients with acute stroke (URICO-ICTUS): a randomised, double-blind phase $2 b / 3$ trial. Lancet Neurol 13:453-460, 2014

20. De Georgia MA, Krieger DW, Abou-Chebl A, Devlin TG, Jauss M, Davis SM, et al: Cooling for Acute Ischemic Brain Damage (COOL AID): a feasibility trial of endovascular cooling. Neurology 63:312-317, 2004

21. del Zoppo GJ: Stroke and neurovascular protection. N Engl J Med 354:553-555, 2006

22. Elkind MS, Sacco RL, Macarthur RB, Peerschke E, Neils G, Andrews H, et al: High-dose lovastatin for acute ischemic stroke: results of the phase I dose escalation neuroprotection with statin therapy for acute recovery trial (NeuSTART). Cerebrovasc Dis 28:266-275, 2009

23. Els T, Klisch J, Orszagh M, Hetzel A, Schulte-Mönting J, Schumacher M, et al: Hyperglycemia in patients with focal cerebral ischemia after intravenous thrombolysis: influence on clinical outcome and infarct size. Cerebrovasc Dis 13:89-94, 2002

24. Feng L, Fitzsimmons BF, Young WL, Berman MF, Lin E, Aagaard BD, et al: Intraarterially administered verapamil as adjunct therapy for cerebral vasospasm: safety and 2-year experience. AJNR Am J Neuroradiol 23:1284-1290, 2002

25. Fisher M, Finklestein SP, Furlan AJ, Goldstein LB, Gorelick PG, Kaste M, et al: Recommendations for standards regarding preclinical neuroprotective and restorative drug development. Stroke 30:2752-2758, 1999
26. Flint AC, Kamel H, Navi BB, Rao VA, Faigeles BS, Conell $\mathrm{C}$, et al: Statin use during ischemic stroke hospitalization is strongly associated with improved poststroke survival. Stroke 43:147-154, 2012

27. Fonarow GC, Zhao X, Smith EE, Saver JL, Reeves MJ, Bhatt DL, et al: Door-to-needle times for tissue plasminogen activator administration and clinical outcomes in acute ischemic stroke before and after a quality improvement initiative. JAMA 311:1632-1640, 2014

28. Fordyce CB, Gersh BJ, Stone GW, Granger CB: Novel therapeutics in myocardial infarction: targeting microvascular dysfunction and reperfusion injury. Trends Pharmacol Sci 36:605-616, 2015

29. French JD, West PM, Von Amerongen FK, Magoun HW: Effects of intracarotid administration of nitrogen mustard on normal brain and brain tumors. J Neurosurg 9:378-389, 1952

30. Friedrich MA, Martins MP, Araújo MD, Klamt C, Vedolin $\mathrm{L}$, Garicochea B, et al: Intra-arterial infusion of autologous bone marrow mononuclear cells in patients with moderate to severe middle cerebral artery acute ischemic stroke. Cell Transplant 21 (Suppl 1):S13-S21, 2012

31. Ginsberg MD: Expanding the concept of neuroprotection for acute ischemic stroke: The pivotal roles of reperfusion and the collateral circulation. Prog Neurobiol 145-146:46-77, 2016

32. Ginsberg MD: Neuroprotection for ischemic stroke: past, present and future. Neuropharmacology 55:363-389, 2008

33. Goyal M, Demchuk AM, Menon BK, Eesa M, Rempel JL, Thornton J, et al: Randomized assessment of rapid endovascular treatment of ischemic stroke. N Engl J Med 372:1019_ 1030,2015

34. Goyal M, Menon BK, van Zwam WH, Dippel DW, Mitchell PJ, Demchuk AM, et al: Endovascular thrombectomy after large-vessel ischaemic stroke: a meta-analysis of individual patient data from five randomised trials. Lancet 387:17231731,2016

35. Griffin JH, Zlokovic B, Fernández JA: Activated protein C: potential therapy for severe sepsis, thrombosis, and stroke. Semin Hematol 39:197-205, 2002

36. Guluma KZ, Hemmen TM, Olsen SE, Rapp KS, Lyden PD: A trial of therapeutic hypothermia via endovascular approach in awake patients with acute ischemic stroke: methodology. Acad Emerg Med 13:820-827, 2006

37. Hacke W, Kaste M, Bluhmki E, Brozman M, Dávalos A, Guidetti D, et al: Thrombolysis with alteplase 3 to 4.5 hours after acute ischemic stroke. N Engl J Med 359:1317-1329, 2008

38. Hahn CD, Manlhiot C, Schmidt MR, Nielsen TT, Redington AN: Remote ischemic per-conditioning: a novel therapy for acute stroke? Stroke 42:2960-2962, 2011

39. Hemmen TM, Raman R, Guluma KZ, Meyer BC, Gomes JA, Cruz-Flores S: Intravenous thrombolysis plus hypothermia for acute treatment of ischemic stroke (ICTuS-L): final results. Stroke 41:2265-2270, 2010

40. Hill MD, Martin RH, Mikulis D, Wong JH, Silver FL, terBrugge KG, et al: Safety and efficacy of NA-1 in patients with iatrogenic stroke after endovascular aneurysm repair (ENACT): a phase 2, randomised, double-blind, placebocontrolled trial. Lancet Neurol 11:942-950, 2012

41. Hockel K, Diedler J, Steiner J, Birkenhauer U, Danz S, Ernemann U, et al: Long-term, continuous intra-arterial nimodipine treatment of severe vasospasm after aneurysmal subarachnoid hemorrhage. World Neurosurg 88:104-112, 2016

42. Holzer M, Cerchiari E, Martens P, Roine R, Sterz F, Eisenburger P, et al: Mild therapeutic hypothermia to improve the neurologic outcome after cardiac arrest. N Engl J Med 346:549-556, 2002 (Erratum in N Engl J Med 346:549$556,2002)$ 
43. Hossmann KA: Viability thresholds and the penumbra of focal ischemia. Ann Neurol 36:557-565, 1994

44. Hougaard KD, Hjort N, Zeidler D, Sørensen L, Nørgaard A, Hansen TM, et al: Remote ischemic perconditioning as an adjunct therapy to thrombolysis in patients with acute ischemic stroke: a randomized trial. Stroke 45:159-167, 2014

45. Jauch EC, Saver JL, Adams HP Jr, Bruno A, Connors JJ, Demaerschalk BM, et al: Guidelines for the early management of patients with acute ischemic stroke: a guideline for healthcare professionals from the American Heart Association/ American Stroke Association. Stroke 44:870-947, 2013

46. Jayaraman MV, Hussain MS, Abruzzo T, Albani B, Albuquerque FC, Alexander MJ, et al: Embolectomy for stroke with emergent large vessel occlusion (ELVO): report of the Standards and Guidelines Committee of the Society of NeuroInterventional Surgery. J Neurointerv Surg 7:316-321, 2015 (Erratum in J Neurointerv Surg 7:622, 2015)

47. Jolkkonen J, Kwakkel G: Translational hurdles in stroke recovery studies. Transl Stroke Res 7:331-342, 2016

48. Jovin TG, Chamorro A, Cobo E, de Miquel MA, Molina CA, Rovira A, et al: Thrombectomy within 8 hours after symptom onset in ischemic stroke. N Engl J Med 372:2296-2306, 2015

49. Kaufmann AM, Firlik AD, Fukui MB, Wechsler LR, Jungries CA, Yonas H: Ischemic core and penumbra in human stroke. Stroke 30:93-99, 1999

50. Khanna A, Kahle KT, Walcott BP, Gerzanich V, Simard JM: Disruption of ion homeostasis in the neurogliovascular unit underlies the pathogenesis of ischemic cerebral edema. Transl Stroke Res 5:3-16, 2014

51. Khanna A, Walcott BP, Kahle KT, Simard JM: Effect of glibenclamide on the prevention of secondary brain injury following ischemic stroke in humans. Neurosurg Focus 36(1):E11, 2014

52. Khatri P, Yeatts SD, Mazighi M, Broderick JP, Liebeskind DS, Demchuk AM, et al: Time to angiographic reperfusion and clinical outcome after acute ischaemic stroke: an analysis of data from the Interventional Management of Stroke (IMS III) phase 3 trial. Lancet Neurol 13:567-574, 2014

53. Kidwell CS, Saver JL, Schubert GB, Eckstein M, Starkman $\mathrm{S}$ : design and retrospective analysis of the Lost Angeles Prehospital Stroke Screen (LAPSS). Prehosp Emerg Care 2:267-273, 1998

54. Krieger DW, De Georgia MA, Abou-Chebl A, Andrefsky JC, Sila CA, Katzan IL, et al: Cooling for acute ischemic brain damage (cool aid): an open pilot study of induced hypothermia in acute ischemic stroke. Stroke 32:1847-1854, 2001

55. Kruyt ND, Biessels GJ, Devries JH, Roos YB: Hyperglycemia in acute ischemic stroke: pathophysiology and clinical management. Nat Rev Neurol 6:145-155, 2010

56. Kwan J, Hand P, Sandercock P: A systematic review of barriers to delivery of thrombolysis for acute stroke. Age Ageing 33:116-121, 2004

57. Linfante I, Cipolla MJ: Improving reperfusion therapies in the era of mechanical thrombectomy. Transl Stroke Res 7:294-302, 2016

58. Lyden PD, Allgren RL, Ng K, Akins P, Meyer B, Al-Sanani $\mathrm{F}$, et al: Intravascular Cooling in the Treatment of Stroke (ICTuS): early clinical experience. J Stroke Cerebrovasc Dis 14:107-114, 2005

59. Lyden P, Hemmen T, Grotta J, Rapp K, Ernstron K, Rzesiewicz T: Results of the ICTuS 2 trial (Intravascular Cooling in the Treatment of Stroke 2). Stroke 47:2888-2895, 2016

60. McGrath RT, Hocking SL, Priglinger M, Day S, Herkes GK, Krause M, et al: Rationale and design of Short-Term Exenatide Therapy in Acute Ischaemic Stroke (STEXAS): a randomised, open-label, parallel-group study. BMJ Open 6:e008203, 2016

61. Meng R, Asmaro K, Meng L, Liu Y, Ma C, Xi C, et al: Upper limb ischemic preconditioning prevents recurrent stroke in intracranial arterial stenosis. Neurology 79:1853-1861, 2012

62. Misra V, Ritchie MM, Stone LL, Low WC, Janardhan V: Stem cell therapy in ischemic stroke: role of IV and intra-arterial therapy. Neurology 79 (13 Suppl 1):S207-S212, 2012

63. Moniche F, Gonzalez A, Gonzalez-Marcos JR, Carmona M, Piñero P, Espigado I, et al: Intra-arterial bone marrow mononuclear cells in ischemic stroke: a pilot clinical trial. Stroke 43:2242-2244, 2012

64. Mosnier LO, Zlokovic BV, Griffin JH: Cytoprotectiveselective activated protein $\mathrm{C}$ therapy for ischaemic stroke. Thromb Haemost 112:883-892, 2014

65. Musahl C, Henkes H, Vajda Z, Coburger J, Hopf N: Continuous local intra-arterial nimodipine administration in severe symptomatic vasospasm after subarachnoid hemorrhage. Neurosurgery 68:1541-1547, 2011

66. Naci H, Brugts JJ, Fleurence R, Ades AE: Comparative effects of statins on major cerebrovascular events: a multipletreatments meta-analysis of placebo-controlled and activecomparator trials. QJM 106:299-306, 2013

67. Newton HB: Intra-arterial chemotherapy of primary brain tumors. Curr Treat Options Oncol 6:519-530, 2005

68. Ní Chróinín D, Asplund K, Åsberg S, Callaly E, CuadradoGodia E, Díez-Tejedor E, et al: Statin therapy and outcome after ischemic stroke: systematic review and meta-analysis of observational studies and randomized trials. Stroke 44:448 456,2013

69. Ní Chróinín D, Callaly EL, Duggan J, Merwick Á, Hannon N, Sheehan Ó, et al: Association between acute statin therapy, survival, and improved functional outcome after ischemic stroke: the North Dublin Population Stroke Study. Stroke 42:1021-1029, 2011

70. Nichol A, French C, Little L, Haddad S, Presneill J, Arabi Y, et al: Erythropoietin in traumatic brain injury (EPO-TBI): a double-blind randomised controlled trial. Lancet 386:24992506, 2015

71. Olsen TS, Larsen B, Herning M, Skriver EB, Lassen NA: Blood flow and vascular reactivity in collaterally perfused brain tissue. Evidence of an ischemic penumbra in patients with acute stroke. Stroke 14:332-341, 1983

72. Petty MA, Wettstein JG: Elements of cerebral microvascular ischaemia. Brain Res Brain Res Rev 36:23-34, 2001

73. Pico F, Rosso C, Meseguer E, Chadenat ML, Cattenoy A, Aegerter $\mathrm{P}$, et al: A multicenter, randomized trial on neuroprotection with remote ischemic per-conditioning during acute ischemic stroke: the Remote Ischemic Conditioning in Acute Brain Infarction study protocol. Int J Stroke 11:938-943, 2016

74. Powers WJ, Derdeyn CP, Biller J, Coffey CS, Hoh BL, Jauch EC, et al: 2015 American Heart Association/American Stroke Association focused update of the 2013 Guidelines for the Early Management of Patients with Acute Ischemic Stroke Regarding Endovascular Treatment: a guideline for healthcare professionals from the American Heart Association/ American Stroke Association. Stroke 46:3020-3035, 2015

75. Prabhakaran S, Ruff I, Bernstein RA: Acute stroke intervention: a systematic review. JAMA 313:1451-1462, 2015

76. Przyklenk K, Bauer B, Ovize M, Kloner RA, Whittaker P: Regional ischemic 'preconditioning' protects remote virgin myocardium from subsequent sustained coronary occlusion. Circulation 87:893-899, 1993

77. Rha JH, Saver JL: The impact of recanalization on ischemic stroke outcome: a meta-analysis. Stroke 38:967-973, 2007

78. Riedel CH, Zimmermann P, Jensen-Kondering U, Stingele R, Deuschl G, Jansen O: The importance of size: successful recanalization by intravenous thrombolysis in acute anterior stroke depends on thrombus length. Stroke 42:1775-1777, 2011

79. Riina HA, Fraser JF, Fralin S, Knopman J, Scheff RJ, Boock- 
var JA: Superselective intraarterial cerebral infusion of bevacizumab: a revival of interventional neuro-oncology for malignant glioma. J Exp Ther Oncol 8:145-150, 2009

80. Rosado-de-Castro PH, Pimentel-Coelho PM, da Fonseca LM, de Freitas GR, Mendez-Otero R: The rise of cell therapy trials for stroke: review of published and registered studies. Stem Cells Dev 22:2095-2111, 2013

81. Saver JL, Goyal M, Bonafe A, Diener HC, Levy EI, Pereira VM, et al: Stent-retriever thrombectomy after intravenous t-PA vs. t-PA alone in stroke. N Engl J Med 372:2285-2295, 2015

82. Saver JL, Kidwell C, Eckstein M, Starkman S: Prehospital neuroprotective therapy for acute stroke: results of the Field Administration of Stroke Therapy-Magnesium (FAST-MAG) pilot trial. Stroke 35:e106-e108, 2004

83. Saver JL, Starkman S, Eckstein M, Stratton S, Pratt F, Hamilton S, et al: Methodology of the Field Administration of Stroke Therapy-Magnesium (FAST-MAG) phase 3 trial: part 1-rationale and general methods. Int J Stroke 9:215219, 2014

84. Saver JL, Starkman S, Eckstein M, Stratton SJ, Pratt FD, Hamilton S, et al: Prehospital use of magnesium sulfate as neuroprotection in acute stroke. N Engl J Med 372:528-536, 2015

85. Sheth KN, Elm JJ, Molyneaux BJ, Hinson H, Beslow LA, Sze GK, et al: Safety and efficacy of intravenous glyburide on brain swelling after large hemispheric infarction (GAMES$\mathrm{RP}$ ): a randomised, double-blind, placebo-controlled phase 2 trial. Lancet Neurol 15:1160-1169, 2016

86. Shields CL, Shields JA: Retinoblastoma management: advances in enucleation, intravenous chemoreduction, and intraarterial chemotherapy. Curr Opin Ophthalmol 21:203-212, 2010

87. Shuaib A, Butcher K, Mohammad AA, Saqqur M, Liebeskind DS: Collateral blood vessels in acute ischaemic stroke: a potential therapeutic target. Lancet Neurol 10:909-921, 2011

88. Simard JM, Chen M, Tarasov KV, Bhatta S, Ivanova S, Melnitchenko L, et al: Newly expressed SUR1-regulated NC(CaATP) channel mediates cerebral edema after ischemic stroke. Nat Med 12:433-440, 2006

89. Simard JM, Sahuquillo J, Sheth KN, Kahle KT, Walcott BP: Managing malignant cerebral infarction. Curr Treat Options Neurol 13:217-229, 2011

90. Skolnick BE, Maas AI, Narayan RK, van der Hoop RG, MacAllister T, Ward JD, et al: A clinical trial of progesterone for severe traumatic brain injury. N Engl J Med 371:2467-2476, 2014
91. van der Worp HB, Macleod MR, Bath PM, Demotes J, Durand-Zaleski I, Gebhardt B, et al: EuroHYP-1: European multicenter, randomized, phase III clinical trial of therapeutic hypothermia plus best medical treatment vs. best medical treatment alone for acute ischemic stroke. Int J Stroke 9:642-645, 2014

92. Walcott BP, Boehm KM, Stapleton CJ, Mehta BP, Nahed BV, Ogilvy CS: Retrievable stent thrombectomy in the treatment of acute ischemic stroke: analysis of a revolutionizing treatment technique. J Clin Neurosci 20:1346-1349, 2013

93. Walcott BP, Kahle KT, Simard JM: Novel treatment targets for cerebral edema. Neurotherapeutics 9:65-72, 2012

94. Walcott BP, Miller JC, Kwon CS, Sheth SA, Hiller M, Cronin $\mathrm{CA}$, et al: Outcomes in severe middle cerebral artery ischemic stroke. Neurocrit Care 21:20-26, 2014

95. Wheeler HM, Mlynash M, Inoue M, Tipirnini A, Liggins J, Bammer R, et al: The growth rate of early DWI lesions is highly variable and associated with penumbral salvage and clinical outcomes following endovascular reperfusion. Int J Stroke 10:723-729, 2015

96. Willeit J, Geley T, Schöch J, Rinner H, Tür A, Kreuzer H, et al: Thrombolysis and clinical outcome in patients with stroke after implementation of the Tyrol Stroke Pathway: a retrospective observational study. Lancet Neurol 14:48-56, 2015

97. Wu TC, Grotta JC: Hypothermia for acute ischaemic stroke. Lancet Neurol 12:275-284, 2013

98. Yilmaz G, Granger DN: Leukocyte recruitment and ischemic brain injury. Neuromolecular Med 12:193-204, 2010

99. Zlokovic BV, Griffin JH: Cytoprotective protein C pathways and implications for stroke and neurological disorders. Trends Neurosci 34:198-209, 2011

\section{Disclosures}

Dr. Amar reports that he has received time-based compensation for research in clinical trials.

\section{Author Contributions}

Conception and design: Mack. Drafting the article: Mack, Babadjouni, Walcott. Critically revising the article: all authors. Reviewed submitted version of manuscript: all authors. Approved the final version of the manuscript on behalf of all authors: Mack.

\section{Correspondence}

William J. Mack, 1520 San Pablo St., Ste. 3800, Los Angeles, CA 90033. email: william.mack@med.usc.edu. 